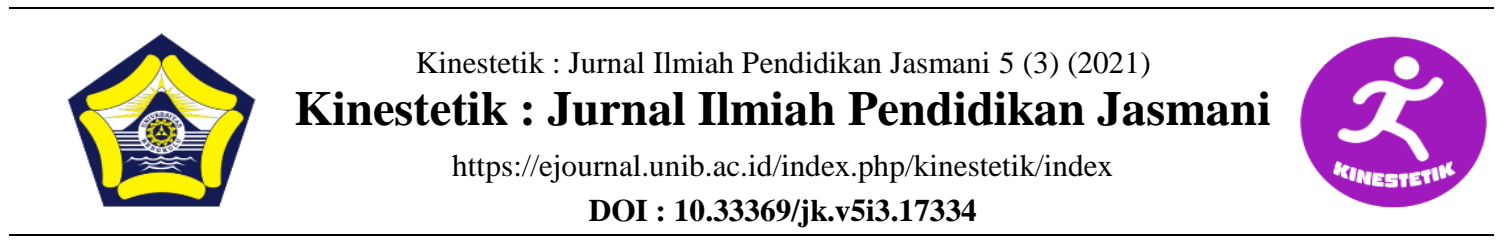

\title{
COLLEGE STUDENTS SPORT ORIENTATION AFTER FOLLOWING BASKETBALL SPORT EDUCATION
}

\section{Fauzan Effendy ${ }^{1 *}$, Riki Ramadhan ${ }^{2}$}

${ }^{12}$ Program Studi Pendidikan Jasmani Kesehatan dan Rekreasi, STKIP Nahdlatul Ulama Indramayu, Jawa Barat, Indonesia

\section{Article Info}

Article History :

Received :August 2021

Revised : September 2021

Accepted : September 2021

Available online : September 2021

Keywords:

Sport Orientation, College Students, Sport Education, Basketball

\begin{abstract}
This study aims to examine the difference in the influence between SE teaching and conventional teaching on student sports orientation using basketball. The research method in this study uses experiment with the randomized pretest-posttest control group design. The participants were 48 students of the PJKR study program at STKIP Nahdlatul Ulama Indramayu. The research instrument uses Sport Orientation Questionnaire for students majoring in sports. The research data were analyzed using independent samples t-test. The results of the study concluded that there were differences in the influence between SE teaching and conventional teaching on student sports orientation using basketball. In order to carry out further research using other sports besides basketball and to conduct further investigations at the end of season tournament using SE.
\end{abstract}

Corresponding address : STKIP Nahdlatul Ulama Indramayu, Jl.

Raya Kaplongan No. 28, Karangampel, Kabupaten Indramayu, Jawa

Barat 45283, Indonesia

*Corresponding email : Fauzan_effendy@stkipnu.ac.id
ISSN 2685-6514 (Online)

ISSN 2477-331X (Print) 


\section{INTRODUCTION}

Graduate competence is one of the many national education standards that need to be improved on a planned and regular basis (UU RI No. 20, 2003). Likewise, Higher Education (i.e College) must be able to produce graduates who have competence by providing learning experiences that will later be useful for the interests of the nation. The development of students to become individuals who believe and compliant to Almighty God, and have noble morals, healthy, knowledgeable, competent, independent, creative, competent, skilled, and civilized for the benefit of the nation (UU RI No. 12, 2012). From the interests of the nation, it is expected that students have competitiveness so that college must be able to facilitate. As an effort to increase the nation's competitiveness in the face of the era of globalization, college must be able to develop science and technology are needed to produce professional academics and not be separated from international competition (UU RI No. 12, 2012).

From the results of the researcher's learning experience during his time as a student, many lecturers who teach sports tend to teach with teachers towards the provision of skills, training, and interspersed with games. In addition, the results of field observations of some fellow lecturers who teach sports are also the same they tend to provide a similar learning experience. In fact, lecturers must have the skills to implement the goals of national education by having pedagogical skills that is to manage the learning of students (UU RI No. 14, 2005).

Most lecturers often use conventional learning. Thus, the lectures that are carried out often use an emphasis on providing repetition of material and demonstrations during the lecture process. The conventional model is learning by using drill (repetition) by means of demonstrations or giving examples of movements (Budi \& Listiandi, 2021). In line with this, in the lecture semester, the process is still using the conventional model (Junanda, 2021).

At this time, lecturers, especially those related to sports major, should provide learning experiences to students in order to facilitate teaching activities that can provide learning experiences through competition, but can be useful for students based on the learning experience. Competition or competition is usually characterized by competitive activities (Ginanjar, Suherman, Juliantine, \& Hidayat, 2019).

In participating in competition activities, it is certain that everyone wants success and achievement while participating in these competitions. Success and achievement orientation is a person's orientation towards competitiveness to be better and sports competition or sports orientation depends on goal orientation (Ginanjar et al., 2019). Therefore, to measure someone who is involved in sports activities can use the Sport Orientation Questionnaire (SOQ). SOQ is mostly used for athletes, but in Indonesia SOQ has been validated for students of junior high school and equivalent, senior high school equivalent, 
and college (Ginanjar, 2019c, 2020; Ginanjar et al., 2019). This relates to the opinion Almond (2014) that competitive sports have important elements that are important for the validity of competitive sports in teaching.

One form of teaching that contains elements of competition through competitive activities can use Sport Education (SE). SE provides an experience for children with competition according to their development and competition is very important for the sports experience (Siedentop, Hastie, \& Mars, 2011). The purpose of SE according to Siedentop were the development of competent, literate, and enthusiastic sportspersons (Metzler, 2000). The development of competent related to having sports skills and knowledge (sports branch), literate related to sports literacy, and enthusiastic sportspersons related to enthusiasm in participating in sports activities (Ginanjar, 2019a; Ginanjar, Mubarok, Mudzakir, \& Mahasiswa Semester 7 Angkatan 2016 PJKR STKIP Nahdlatul Ulama Indramayu, 2021).

The results of research using SE outside Indonesia have focused on preservice, one of the criteria is that students are involved in using SE (Hordvik, Macphail, \& Ronglan, 2017). Must examine the effectiveness of encouraging lecturers and students to work together as a learning community that learns from each other (Luguetti, Lopes, Sobrinho, Carbinatto, \& Macphail, 2018). SE keeps students motivated in learning at college (André \& Hastie, 2017). SE as an appropriate pedagogy for sports colleges which is considered to be very motivating for students (André \& Hastie, 2017).

SE search results in Indonesia related to new sports orientation were carried out on junior high school students using basketball and badminton (Ginanjar, 2018; Ginanjar et al., 2019), while in college no one has conducted research related to sports orientation and only SE is related to motivation (Ginanjar, Mubarok, \& Mudzakir, 2021). The results of the SE research on sports orientation in junior high school that SE is better than conventional (Ginanjar, 2018), and students who learn to use basketball using SE have a better effect than students who learn to use badminton SE on sports orientation (Ginanjar et al., 2019). Therefore, this study aims to examine the difference in the effect between SE teaching and conventional teaching on student sports orientation using basketball.

\section{METHODS}

The research method used an experiment with the randomized pretestposttest control group design. The randomized posttest-only control group design involves two groups, both of which are formed by random assignment. One group receives the experimental treatment while the other does not, and hen both groups are posttested on the dependent variable (Fraenkel, Wallen, \& Hyun, 2012).

\section{Participants}

Participants came from a
population of 48 students from the
Physical Education major who took
basketball courses.

\section{Sampling Procedures}

If the population is only 100 then the sample used is at least $50 \%$ of the total population, therefore, the entire population is sampled (Ginanjar, 2019b). To divide the experimental and control 
groups using simple random sampling, each group consists of 24 people with random assignment. Random assignment means that every individual who is participating in an experiment has an equal chance of being assigned to any of the experimental or control conditions being compared (Fraenkel et al., 2012).

\section{Materials and Apparatus}

The research instrument uses SOC for students majoring in sports (Ginanjar, 2019c). The SOQ consists of three sub-scales: competitiveness with a reliability construct of 0.95 , a winning orientation with a reliability construct of 0.91 , and a goal orientation with a reliability construct of 0.91 using 17 test items. Competitiveness consists of 9 test items, winning orientation consists of 5 test items, and goal orientation consists of 3 test items with CMIN $=213.09$ and $\mathrm{DF}=116$ with $\mathrm{CMIN} / \mathrm{DF}=1.84<2$. RMSEA $=0.07$ between $0.05-0.08$ with NFI, PNFI, CFI, IFI, RFI, GFI, AGFI with respective values of 0.92 , $0.78,0.96,0.96,0.91,0.86,0.81$. For more details, please see the work Ginanjar (2019c).

\section{Procedures}

The treatment in this study was both the experimental class and the control class as many as 15 meetings. For the experimental class using SE which adapts the work Ginanjar et al. (2019), while for the control class using conventional teaching with basketball sports. The difference in treatment can be seen in Table 1 .
Table 1. Differences in Treatment Class Experiment (SE) and Class Control (Conventional)

\begin{tabular}{|c|c|c|}
\hline Lesson & SE & Conventional \\
\hline 1 & $\begin{array}{l}\text { - Basketball } \\
\text { introduction } \\
\text { - Need assesmen } \\
\text { - Identification } \\
\text { of team coach } \\
\text { - Team selection } \\
\text { and team name } \\
\text { - Student role } \\
\text { rules }\end{array}$ & $\begin{array}{l}\text { - Basketball } \\
\text { introduction }\end{array}$ \\
\hline 2 & $\begin{array}{l}\text { Team practice } \\
\text { - Passing } \\
\text { - } \quad \text { Game }\end{array}$ & $\begin{array}{l}\text { Passing } \\
\text { - Technique } \\
\text { drill } \\
\text { - Game }\end{array}$ \\
\hline 3 & $\begin{array}{l}\text { Team practice } \\
\text { - Dribbling } \\
\text { - Game }\end{array}$ & $\begin{array}{l}\text { Dribbling } \\
\text { - Technique } \\
\text { drill } \\
\text { - Game }\end{array}$ \\
\hline
\end{tabular}

\begin{tabular}{|c|c|c|}
\hline 4 & $\begin{array}{l}\text { Team practice } \\
\text { - Shooting } \\
\text { - } \quad \text { Game }\end{array}$ & $\begin{array}{l}\text { Shooting } \\
\text { - Technique } \\
\text { drill } \\
\text { - Game }\end{array}$ \\
\hline 5 & $\begin{array}{l}\text { Team practice } \\
\text { - Offence atau } \\
\text { defence } \\
\text { - Game }\end{array}$ & $\begin{array}{l}\text { Offence/defenc } \\
\text { e } \\
\text { - Technique } \\
\text { drill } \\
\text { - Game }\end{array}$ \\
\hline 6 & $\begin{array}{l}\text { Team practice } \\
\begin{array}{l}\text { - } \\
\text { segular } \\
\quad \text { season }(3 \mathrm{v} 3)\end{array}\end{array}$ & - Game (5v5) \\
\hline 7 & $\begin{array}{l}\text { Team practice } \\
\text { - } \quad \text { Regular } \\
\quad \text { season }(3 v 3)\end{array}$ & - Game (5v5) \\
\hline 8 & $\begin{array}{ll}\text { Team practice } \\
\text { - } & \text { Regular } \\
& \text { season }(3 \mathrm{v} 3) \\
\end{array}$ & - Game (5v5) \\
\hline 9 & $\begin{array}{ll}\text { Team practice } \\
\text { - } & \text { Regular } \\
& \text { season }(3 \mathrm{v} 3)\end{array}$ & - Game (5v5) \\
\hline
\end{tabular}




\begin{tabular}{|c|c|c|}
\hline 10 & $\begin{array}{l}\text { Team practice } \\
\text { - } \quad \text { Regular } \\
\quad \text { season }(3 \mathrm{v} 3)\end{array}$ & - Game (5v5) \\
\hline 11 & $\begin{array}{l}\text { Postseason } \\
\text { tournament }\end{array}$ & Tournament \\
\hline 12 & $\begin{array}{l}\text { Postseason } \\
\text { tournament }\end{array}$ & Tournament \\
\hline 13 & $\begin{array}{l}\text { Postseason } \\
\text { tournament }\end{array}$ & Tournament \\
\hline 14 & $\begin{array}{l}\text { Postseason } \\
\text { tournament }\end{array}$ & Tournament \\
\hline 15 & $\begin{array}{ll}\text { - } & \text { Final } \\
\text { - } & \text { Award } \\
& \text { ceremony } \\
\end{array}$ & Tournament \\
\hline
\end{tabular}

\section{Design or Data Analysis}

Data analysis using descriptive statistics in the mean difference, standard deviation, and variance and significance test were analyzed using independent samples t-test with the help of IBM SPSS 24 application, analysis procedure following (Ginanjar, 2021).

\section{RESULTS}

In Table 2 for the experimental class, the average is 75.58 , the standard deviation is 4.52 , and the variance is 20.43. For the control class obtained an average of 75.58, standard deviation of 4.52 , and variance of 20.43 .

In Table 3, the tcount value is 4.43 with a significance value of 0.00 $<0.05$, so there is a difference in the effect between SE teaching and conventional teaching on student sports orientation using basketball, where SE teaching is more influential than conventional teaching.
Table 2. Recapitulation of Statistics Description

\begin{tabular}{ccc}
\hline & $\begin{array}{c}\text { Experiment } \\
\text { Class }\end{array}$ & $\begin{array}{c}\text { Control } \\
\text { Class }\end{array}$ \\
\hline Mean & 75.58 & 66.96 \\
\hline Std. Dev. & 4.52 & 8.16 \\
\hline Varian & 20.43 & 66.56 \\
\hline
\end{tabular}

Table 3. Recapitulation of Independnet Samples T-Test

\begin{tabular}{lcc}
\hline & $\mathbf{t}_{\text {count }}$ & Sig. \\
\hline $\begin{array}{c}\text { Experiment Class } \\
>< \\
\text { Control Class }\end{array}$ & 4.53 & 0.00 \\
\hline
\end{tabular}

From the results of the study, it was found that there were differences in sports orientation between SE teachers and conventional teachers where SE had more influence on sports orientation according to the statement of Siedentop et al. (2011).

\section{DISCUSSION}

SE provides students with competitive experiences according to their development and competition is very important for the sports experience. This also supports the statement that when competition is given in the right way or the right model will provide a sense of security in teaching (Ginanjar, Suherman, Juliantine, \& Hidayat, 2018), for now or in the future (Layne, 2014). The results of this study support and expand SE that in the presence of competition it is in accordance with the statement that SE can be used in competitive sports (Ginanjar et al., 2019) and with SE competitiveness using 
competition is fun (Bennett \& Hastie, 1997).

The results of observations in the field that with SE students and their groups are more enthusiastic in practicing, they seem to have interdependence with one another. They enjoy using SE more because they already have a complete and clear procedure from the beginning of the season to the end of the teaching season. This is in line with what is recommended by Ginanjar (2019a); Siedentop et al. (2011) that it is important in the use of $\mathrm{SE}$ to design programs from the beginning of the season to the end of the season so that teaching using SE can run smoothly such as: planning, selecting sports, student involvement, identifying and preparing materials used, modifying games and others according to the characteristics of SE.

They feel that practicing in every meeting is important as a way to improve their skills and team cohesiveness because they know there will be a competition or tournament at the end of the season. In line with that Layne (2014) also stated that students receive opportunities to practice skills and can use these skills in game situations. However, although they enjoy the process of using SE, they still think that they must be able to become champions in the competition activity. This is in accordance with the opinion that a competitive situation will trigger positive outcomes for winners and losers (Layne, 2014), it could even allow for negative results as well.
The results of this study also support that SE with competition, pay attention to recommendations for competition using SE according to Ginanjar et al. (2018); Layne (2014) so that competition using SE can run safely such as: to always provide an understanding of all aspects of sports, provide more development-oriented teaching rather than results, give rewards to all teams involved, don't let teaching become too competitive, and keep having fun using SE in teaching. So that this study provides suggestions for conducting further research with the recommendations suggested by Ginanjar et al. (2018); Layne (2014) because there are still statements that must be a champion in the competition activities carried out.

When viewed from the average obtained, it is not too far away, the average result obtained is only six points. This illustrates that indeed the existence of tournaments in teaching will provide a sense of fun in teaching. Because from observations in the field, students who learn to use conventional teaching seem more enthusiastic about participating in teaching when a tournament is held, even though the tournament does not reveal who the winner of the tournament is. But spontaneously they calculate for themselves that the team that wins the most matches is considered the winner. Unlike students who learn to use SE because the tournament has a clear place and time, how the tournament format is used, and at the end of the season there 
is a final match and celebrations such as awarding trophies. It seems that these characteristics make the SE teaching that has been done has a better effect than conventional teaching. However, further investigation is needed from these findings because they are also supported by research results from Hastie, Ward, \& Brock (2016) which provides strong support for competition in SE.

With the success of SE at the college level in this study, researchers suggest that SE is better used as the basis for the curriculum of major programs, especially majors that related to sports in subjects that use sports branches to use SE as a strategy in teaching and be developed with continuous research. The most important thing is to be able to answer what the researcher experienced while being a student. Because most lecturers who teach sports tend to teach with conventional teaching and research colleagues also tend to provide a similar learning experience to the students they teach.

\section{CONCLUSION}

This study concludes that there is a difference in the effect of SE teaching and conventional teaching on student sports orientation using basketball. This study provides suggestions for conducting further research using sports other than basketball and conducting further investigations during the end of season tournament using SE. This study was conducted on students at the University so that it is necessary to reinvestigate the use of SE at the elementary and secondary school levels related to sport orientation..

\section{ACKNOWLEDGEMENT}

The author conveys the greatest thanks to the Ministry of Research and Technology / BRIN Deputy for Research and Development Strengthening in providing research grants for the 2021 fiscal year so that this research can be realized.

\section{REFERENCES}

Almond, L. (2014). Does competitive sport have educational validity in physical education? Science \& Sports, 29, S51. Elsevier Masson SAS.

https://doi.org/10.1016/j.scispo.2014 .08 .102

André, M. H., \& Hastie, P. (2017). Sport Education in a Higher Education physical activity course. European Journal of Physical Education and Sport Science, 3(6), 22-35. https://doi.org/10.5281/zenodo.5833 65

Budi, D. R., \& Listiandi, A. D. (2021). Model Pembelajaran Dalam Pendidikan Jasmani. Retrieved from https://osf.io/xzh3g/\%0Aosf.io/kduy $\mathrm{n}$

Fraenkel, J. R., Wallen, N. E., \& Hyun, H. . (2012). How to Design and Evaluate Research in Education (Eight Edit). New York: McGrawHill Companies.

Ginanjar, A. (2018). Pengaruh Sport Education Model Bulu Tangkis Terhadap Orientasi Olahraga Siswa SMP. BIORMATIKA, 4(2), 280 287.

Ginanjar, A. (2019a). Implementasi Praktis Sport Education Model. 
Indramayu: Program Studi Pendidikan Jasmani Kesehatan dan Rekreasi STKIP Nahdlatul Ulama Indramayu.

Ginanjar, A. (2019b). Metode Penelitian Kuantitatif dalam Pendidikan Jasmani dan Olahraga. Indramayu: Program Studi Pendidikan Jasmani Kesehatan dan Rekreasi STKIP Nahdlatul Ulama Indramayu.

Ginanjar, A. (2019c). Validasi Instrumen Sport Orientation Questionnaire Untuk Mahasiswa. Jurnal Keolahragaan, 5(2), 20-29.

Ginanjar, A. (2020). Validasi instrumen sport orientation questionnaire untuk siswa Sekolah Menengah Kejuruan Sederajat. Journal of Physical and Outdoor Education, 2(1), 36-46. https://doi.org/10.37742/jpoe.v2i1.2 2

Ginanjar, A. (2021). Statistika Terapan Dalam Pendidikan Jasmani \& Olahraga: Aplikasi Microsoft Excel \& SPSS. Yogyakarta: Deepublish.

Ginanjar, A., Mubarok, M. Z., \& Mudzakir, D. O. (2021). "College Students" Motivation after Teaching Using Sport Education Season. International Journal of Human Movement and Sports Sciences, 9(4A), 1-7. https://doi.org/10.13189/saj.2021.09 1301

Ginanjar, A., Mubarok, M. Z., Mudzakir, D. O., \& Mahasiswa Semester 7 Angkatan 2016 PJKR STKIP Nahdlatul Ulama Indramayu. (2021). Mengetahui, Mengenal, Mempraktikan, dan Merancang Sport Education Menggunakan Cabang Olahraga Futsal. Indramayu: Program Studi Pendidikan Jasmani Kesehatan dan Rekreasi STKIP Nahdlatul Ulama Indramayu.

Ginanjar, A., Suherman, A., Juliantine, T., \& Hidayat, Y. (2018).
Competitive in Physical Education Using Sports Education Model. 3rd International Conference on Sports Science, Health and Physical Education, 11, 282-284. Bandung: Advances in Health Sciences Research. https://doi.org/10.2991/icsshpe18.2019 .80

Ginanjar, A., Suherman, A., Juliantine, T., \& Hidayat, Y. (2019). Sports Orientation during Learning Team or Individual Sports using A Sport Education Model. Cakrawala Pendidikan, 38(2), 377-386. https://doi.org/10.21831/cp.v38i2.24 021

Hastie, P. A., Ward, J. K., \& Brock, S. J. (2016). Effect of graded competition on student opportunities for participation and success rates during a season of Sport Education. Physical Education and Sport Pedagogy, 22(3), 316-327. https://doi.org/10.1080/17408989.20 16.1203888

Hordvik, M. M., Macphail, A., \& Ronglan, L. T. (2017). Teaching and Learning Sport Education: A SelfStudy Exploring the Experiences of a Teacher Educator and Pre-Service Teachers. Journal of Teaching in Physical Education, 36(2), 232-243. https://doi.org/10.1123/jtpe.20160166

Junanda, S. (2021). Tingkat Motivasi Mahasiswa PJKR STKIP Nahdlatul Ulama Indramayu Setelah Mengikuti Sport Education Bola Voli. Jurnal Kependidikan Jasmani Dan Olahraga, 2(1), 36-44.

Layne, T. E. (2014). Competition within Physical Education: Using Sport Education and Other Recommendations to Create a Productive, Competitive Environment. Strategies: A Journal for Physical and Sport Educators, 
27(6),

https://doi.org/10.1080/08924562.20

14.960124

Luguetti, C., Lopes, P., Sobrinho, D. R. de S., Carbinatto, M. V., \& Macphail, A. (2018). The complexity, tensions and struggles in developing learning communities throughout a Sport Education season. European Physical Education Review, 25(4), 10751092.

https://doi.org/10.1177/1356336X18 802285

Siedentop, D., Hastie, P. A., \& Mars, H. van der. (2011). Complete Guide to Sport Education. Champaign: Human Kinetics.

UU RI No. 12. (2012). Pendidikan Tinggi. Jakarta: Republik Indonesia. 